\title{
Religious Pluralism and Multinational Federalism in Bosnia and Herzegovina
}

\author{
Soeren Keil
}

Canterbury Christ Church University

\section{Introduction}

The recognition of national diversity and its accommodation via federalism and autonomy have become key features in Europe and beyond since the end of the Cold War. New models of federalism and territorial autonomy address issues around national diversity in many European countries (Belgium, Spain, Italy) and beyond (Russia, Ethiopia, Nigeria, Iraq). ${ }^{1}$

This contribution will focus on the role of religious pluralism in Bosnia and Herzegovina. ${ }^{2}$ Bosnia is a distinctively multinational state, in which three groups (Bosniaks, Serbs and Croats) are characterized as constituent peoples and together they represent more than 90 per cent of the Bosnian population. ${ }^{3}$ Whilst Bosniaks, Serbs and Croats are clearly favored by the Constitution and therefore enjoy special privileges within the institutions and territorial units, they are similar in many respects: they speak the same language, they share the same history (but not the same interpretation of the past), they all follow certain customs and they all consider Bosnia as their historic homeland. The main distinction between the three groups in Bosnia is religion, Bosniaks are Muslims, while Serbs are Orthodox Christian and Croats are Catholic. Therefore, Bosnia's multinational federal system can be described as a mechanism to accommodate religious diversity in the country. Religion plays a central role in the self-identification of people and thereby influences not only the engagement with other members of the same (religious) group, but also the interaction with members of other groups.

This paper chapter will progress in the following steps: it will begin with a general overview of Bosnia, its different ethnic and religious groups, and the country's current political system. In this context, it will also be discussed how religion acts as the most important marker of the three main groups in Bosnia. In a second step, the relationship between nationalism, religion and territoriality will be explored. This part will demonstrate how federalism has been used to address the demands of the three national groups, but how it has failed to calm demands for secession and further autonomy. Finally, the third section will look at current developments in the country, focusing specifically on a 2009 judgment of the European Court of Human Rights ${ }^{4}$ and its influence on the dynamics of nationalism, religion and territoriality in Bosnia.

The main argument of this contribution is that religion has become the most important national marker in Bosnia. Federalism has been used as the main strategy to address different national (and consequently also religious) issues in the country. Yet, so far the federal system has not resulted in a stable democratic state, but in a polity that remains internally and externally contested. Religious leaders have contributed to this contest and continue to influence political dynamics.

\section{Religion and Nationalism in Bosnia and Herzegovina}


Bosnia is a relatively young country.-- Iit only became a sovereign state in April 1992, when it declared its independence from Yugoslavia, where it was previously one of the six constituent republics. ${ }^{1}$ The referendum which preceded the declaration of independence saw an overwhelming majority of those voting in favor of Bosnia becoming independent. However, the vast majority of Serbs in Bosnia boycotted the referendum and Bosnian Serb authorities, with the support of the Yugoslav army, established autonomous districts and started a military campaign to conquer and ethnically cleanse as much territory as possible. Their main aim was to secede from the newly independent state and conquer large amounts of territory (Burg and Shoup 1999). While initially very successful, the Serbs had to give up territory after NATO intervened in the conflict in 1995, and Croatian forces (from Croatia) properly supported Bosniaks and Bosnian Croats. As a result of the war more than 100,000 people died and more than two million were displaced. Its infrastructure was shattered, its industrial production nearly non-existent and the distance, distrust and hatred between the three main groups greater than ever before. In these circumstances federalism was introduced as a mechanism to manage the conflict between these national groups and provide a framework in which they could live together in one state.

Historically, Bosnia has always been a country of three main groups, nowadays identified as Bosniaks, Serbs and Croats, there is also a long tradition of conflict (as well as cooperation) between these. The main marker of identity in Bosnia is religion. The current religious set-up of the country goes back to the Middle Ages, when it was conquered and ruled by the Ottomans, which remained in charge of Bosnia until 1878. As a result of the Ottoman occupation, three clearly identifiable religious groups developed in the area: Muslims, Catholics and Christian Orthodox (Hoare 2007, Malcolm 2002). These groups developed into ethnically conscious groups in the nineteenth and twentieth centuries. Serbia and Croatia, as well as flourishing ideas of a joint Slav state, ${ }^{2}$ played a pivotal role in a growing consciousness of Serbs and Croats as ethnic (and later also national-with a claim to a certain territory) groups. It is interesting that the discourse of Croats and Serbs from Croatia and Serbia respectively always included Bosnia as well as part of their nation’s territorial homeland. Having said this, it is also important that there were alternative modes of identification as well. Marko Attila Hoare (2007, p. 57) argues about the creation of ethnic identity that

National consciousness in Bosnia-Herzegovina was born in towns and, among members of each of the three nationalities, possessed a Bosnian character that was ready to embrace members of the others. Yet, it was the ethno-religiously 'pure' character of the villages that

${ }^{1}$ Bosnia has never been an independent country before 1992. While a Bosnian Kingdom existed in the Middle Ages, this was conquered and incorporated by the Ottomans in the $15^{\text {th }}$ century.

${ }^{2}$ Bosnians for a long time supported a joint state of all South Slavs. They supported the establishment of the first joint state, the Kingdom of Serbs, Croats and Slovenes after the First World War and they mainly supported the establishment of Communist Yugoslavia after the Second World War as well. In fact, in Yugoslavia Bosnia was the Republic where the highest amount of people could be found that identified as "Yugoslavs." The idea of a joint state failed when Slovenia and Croatia declared their independence from Yugoslavia and many Bosniaks and Croats in Bosnia feared that they would become oppressed in a now-Serb dominated rump-Yugoslavia. 
ultimately imposed its stamp in the national movements, ensuring that they would be unable to bridge the religious divide.

For a long time, Muslims were identified as Serbs or Croats respectively, until 1963 when the Yugoslav Communists allowed them to identify as an ethnic group in Bosnia. In 1971, Bosnia became officially recognized as a nation in Yugoslavia (Babuna 1999). ${ }^{5}$ It is very important to keep in mind that the three main groups, in addition to smaller minority groups, such as Roma and Jews, have been living next to each other in Bosnia for centuries. Their tradition, culture, language and history are the same, despite the lack of a common historical narrative. Hence, the main distinguishing element amongst the three constituent nations in Bosnia remains religion. Ethnic and national identity is strongly connected to religious belonging and contributes to the creation of national discourses of inclusion and exclusion. It comes therefore as no surprise that as a result of the war in Bosnia 19921995, there has also been a revival of religion; religious leaders are becoming more important actors;, a role previously denied to them by the Communist regime in Yugoslavia.

The war between 1992 and 1995 was as much about the nature of the country "Bosnia and Herzegovina” as it was about the relationship of the three main religious/national groups to this country as well as to each other. Serbs frequently argued that Bosniaks were trying to establish an Islamic State in Bosnia, and Croats claimed several times during the war that Bosniaks and Serbs were planning to cleanse Bosnia of all Catholics. Indeed, the Vatican played a very important role in supporting first Croatia and later Croats in Bosnia in their quest for recognition and international support. Turkey and other Muslim countries sided with the Bosniaks, whilst Serbs received particular support from Greece, Russia and other Orthodox states. This is reflected in Samuel Huntington's "Clash of Civilizations" (1993), which includes a discussion on the war in Bosnia as an example of religious conflict. The Peace Agreement (1995), which lays the foundation of the current political system, has been able to provide a framework in which war has become unlikely, but it has been unable to address these existential questions in a stabilizing manner.

Moreover, the conflicts and contrasts between these three groups have overshadowed others in Bosnia. There are fourteen recognized minorities in the country, as well as those citizens that declare themselves as Bosnians or even as Yugoslavs. While they had been marginalized before the war, they have now become victims of a political system, which is built exclusively around the accommodation of the conflict between the three national groups.

\section{Nationalism, Religion and Territoriality}

As described above, religion is the most important marker for the national groups in Bosnia. Yet, in Formatted: Font color: Auto the past they have lived inter-mixed, particularly in the bigger cities. Indeed, Sarajevo remains one of the only cities in the world, where a Mosque, a Catholic Church and an Orthodox Church can be found within one hundred meters from each other. During socialist Yugoslavia, religion played a less important role in public life. While the Yugoslav Communists were not as openly opposed to religious 
expression and practices as other Communist leaders, they cracked-down ontad a crack-dow-on-all major religious organizations when they were seen as a threat to the ruling Communist system. ${ }^{6}$

Despite-As a result of massive population changes during and after the war, there is hardly any territorial unit in which these groups live inter-mixed. Instead, Bosnia has become a country in which different territorial units are mono-ethnic, subsequently there is little exchange between the different peoples. ${ }^{-3}$ The massive efforts by international actors to undo the results of ethnic cleansing have had very limited success (Toal and Dahlman 2011). Because of this creation of homogenous territories as a result of ethnic cleansing, federalism has been used as an appropriate concept to address the on-going nation-building projects amongst the main Bosnian peoplesss. Hence, international actors have used federal autonomy to provide each of the national groups with autonomy in the territory that they control. ${ }^{7}$ However, none of the Bosnian peoples and their representatives preferred a federal option in 1995, instead Serbs and Croats would have preferred their integration into neighboring states, and Bosniaks preferred a more centralized state. Therefore it is possible to refer to the federal system applied in Bosnia as a form of imposed federalism, which outsiders promoted as a tool of conflictresolution and state-building in order to end the violent conflict in the country (Keil 2013a, 2012).

External actors, particularly American negotiators saw the Bosnian conflict as an example of different national groups fighting over the control of territory (Daalder 2000). However, as Burg and Shoup (1999) have demonstrated, the Bosnian war was much more than this. It was about the question of what Bosnia is; the nature of the state; the relationship between Bosniaks, Serbs and Croats to the state; and the relationship of Bosniaks, Serbs and Croats to each other. In other words, it was about different conceptions of Bosnia; one which was exclusive and focused on the dominance of one group over another, and other conceptions which emphasized the multinational, multi-religious and multicultural character of the country. By implementing a federal system which provides autonomy for homogenous territorial units, the concept of group dominance and exclusivity prevailed over alternative approaches.

It is important to highlight that while religion is the main national marker, the ethnic identities in Bosnia should also be seen independently from their religious connotations. The political system created in Dayton focused explicitly not on religious identity, but on ethnic and national criteria. Instead, the human rights provisions of the Dayton constitution allow for the freedom of religion and religious protection even for minority groups. In practice this means that an Orthodox Christian that chooses not to identify as a Serb will not enjoy the privileges given to Serbs in the constitution. It can also mean that a Muslim that chooses to identify as a Serb or a Croat will be given the privileges of these constituent peoples and will be treated as a Serb/Croat according to the constitution. ${ }^{8}$ Having

${ }^{3}$ Before and during the war many people were forced to choose their aliegance. Religious organizations played a key role in manipulating people's self-identification. Many non-believers were forced to choose which religion (and consequently which ethnic group) they belong to. While some refused to identify with any group, most nonbelievers and those identifying as "Bosnians" chose to support the Army of Bosnia and Herzegovina, to fight for the independence and sovereignty of the Bosnian state. However, due to political manipulations the Army of BiH developed more and more into a Bosniak army after 1993. See on this issue Hoare 2004. 
said this, the political system that resulted from the Dayton Peace Agreement has enshrined institutions, in which religious identification as a marker of ethnic/national identification remains of key importance. Because most of Bosnia's territorial units are homogenious and the power-sharing system implemented through Dayton focuses strongly on the three constituent peoples, religion remains the key national marker. This is also, as discussed above, the result of religion as the main difference between the three ethnic groups. Because federalism was used to address the ethnic diversity of the country by creating homogenous units, it has also strengthened religion as a national marker to ensure, protect and enhance homogenization processes in these territorial units.

The system created in a peace treaty in 1995 in Dayton, Ohio, has become one of the most complex and decentralized in the world. Bosnia was established as a federal state based on two entities, the Federation of Bosnia and Herzegovina (FBiH), which itself consists of ten cantons, and the Republika Sprska (RS), in which mainly Serbs live. All territorial units, with the exception of two mixed cantons in the Federation and the District of Brčko in the North, are homogenous, i.e. one national group has an absolute majority. The FBiH covers $51 \%$ of the territory, and consists of ten cantons, of which five have a Bosniak majority, three have a Croat majority and two are mixed (mainly between Bosniaks and Croats). The RS is not organized into cantons, but uses municipalities as administrative units. However, in contrast to the $\mathrm{FBiH}$, where most decisions are left to the cantons, the RS is highly centralized. In addition to this complex territorial system, power-sharing institutions have been introduced at the central level (Bieber 2006). Bosniaks, Serbs and Croats have to work together in key institutions. For example, the Bosnian Presidency consists of three members, one Bosniak and one Croat, both elected in the $\mathrm{FBiH}$, and one Serb, who is elected in the RS. Furthermore, the government always consists of a Bosniak, Serb and Croat party. Representatives of the three national groups also have substantial veto rights based on group and entity concerns. In short, all territorial issues in Bosnia are also issues connected to the national groups, and all issues which effect the three constituent peoples are also territorial. This combination of territory and national identity is highly problematic, as it means that literally all political issues become a contest between three different national groups, which enjoy a vast amount of autonomy in the territorial units in which they are a majority (Bieber and Keil 2009). It is important to keep in mind that the federal system, including its power-sharing elements, hasve been implemented as part of a peace treaty to end the war and ensure Bosnia's territorial integrity. However, they these institutional provisions have never been designed to provide a long-term framework for the country, instead it was hoped that Bosnians from all backgrounds would be able to give themselves a new Constitution once violence has ended and the peace agreement has been implemented. More than ten years after the end of the war, there is still no new Constitution for the country. It remains governed by a set of rules which were written by the US State Department and the only official version of Bosnia's Constitution remains written in English. ${ }^{9}$

Once peace was established in Bosnia in 1995 and 1996, Bosnia’s politicians were asked to implement the Dayton Peace Agreement, particularly focusing on the human rights provisions, refugee 
return, rebuilding basic infrastructure and enabling economic development. In addition to this, international actors focused on the restructuring of basic state structures, including central institutions, border control posts, and providing unified passports and documents to Bosnian citizens. In this context it became clear that the main party elites would never agree on major policy issues, because they never agreed to the Bosnian state and its internal organization in the first place. They failed to decide on important issues including the design of passports, the look of the Bosnian flag and its national symbols. The territories mainly occupied by Croats in Bosnia were economically and structurally integrated into Croatia properly (including the introduction of the Croatian Kuna as the main currency), and the RS continued its strong links with Serbia (including the use of the Serbian/Yugoslav Dinar as the main currency). Bosnia after 1995 was neither unified, nor were its political elites cooperating. ${ }^{10}$ The international community intervened in 1997 by giving the High Representative, the highest civilian authority of the Peace Agreement, the power to impose laws and dismiss officials. ${ }^{11}$

Once international actors, most notably the High Representative, ${ }^{12}$ received far-reaching intervention rights, Bosnia became a major example of international state-building (Belloni 2007). Some of the fundamental decisions that have been implemented by different High Representatives include a new Law on Citizenship, a Law on National Symbols (including the design of the Bosnian flag), a Law on a State Border Police, and further laws enabling the central institutions to access independent funds. All efforts to build a state in Bosnia were directed towards two main aims. First, international actors focused on making the central level, as well as the local levels, more efficient by weakening some of the strict power-sharing rules. This was achieved through a process of legal changes, in which some of the strict power-sharing rules were clarified and abolished. For example, the rotation of the Chair of the Council of Ministers (Bosnia's government) has been abolished, so has the fact that each Minister must have two Deputy-Ministers from the other national group. The Constitutional Court has also been vital in abolishing these strict and excessive power-sharing mechanisms, which have been responsible for delays, vetoes and a general weakening of the central institution. Second, all international interventions have focused on centralization (Keil 2013, 106-7). Because Bosnia was such a decentralized system after 1995, in which only three ministries existed at central level, it was of key importance to strengthen the central state level in order to provide any form of re-integration and counterbalance the continued attempts of de-facto and de-jure secession of the Croat and Serb parts of the country. Until 2006, as a result of international intervention and pressure from the international donor community, six more ministries were established. An important tax reform in 2006 also ensured that the central institutions would receive independent funding, instead of being totally dependent on the entities. A military reform in the same year ensured that the entities gave up control over military matters and a central Defense Ministry was established. ${ }^{13}$ Some of these reforms have had a positive effect on the role of the central institutions, and it became more and more impossible for Bosnian Serbs and Croats to ignore the central institutions and focus on those territories 
in which they were a majority. However, local and international observers worried about a lack of democratic legitimacy of reforms that were initiated or imposed by international actors. Amongst these, David Chandler (2000) called Bosnia a "faked democracy” and in 2007 the Chairperson of the Council of Ministers argued that

Bosnia-Herzegovina is absurd. If the international community always supports the high representative and not the institutions of Bosnia-Herzegovina, then it doesn't matter if I am the head of that state or Bart Simpson (Spiric 2007).

There remains a heated debate about the legitimacy and appropriateness of international intervention and state-building, and Bosnia remains an example at hand, which seems to suggest that external statebuilding in some areas can be very successful, while a general consensus on the state needs to exist in order to establish functional and legitimate institutions. ${ }^{14}$

For our discussion here, it is important to look at Bosnia as an example of imposed federalism, an ideology that was seen as the appropriate framework to end a violent conflict. However, because none of the three national/religious groups agreed on a federal solution in 1995, they were never willing to make this federal system work. Hence, they rejected the implementation of the peace plan, including its human rights and power-sharing provisions. Instead, the international community had to step in and ensure some progress in the implementation of the peace agreement and the reestablishment of stateness in the country. However, international interventions, impositions and the dismissal of democratically elected officials have been criticized for being undemocratic and neocolonial (Knaus and Martin 2003). In many respects these international interventions have strengthened national and identification identification within the main groups in Bosnia, as political parties were able to utilize these interventions to create an "us" versus "them" (meaning external actors) atmosphere. Bosnia can be classified as an internationally administered federation (Keil 2013, 121-123), in which international actors took important decisions and contributed to the implementation of a peace plan and a constitutional framework, where local elites had previously failed. The state itself was not built on the consensus of the main actors, the three main constituent peoples never agreed on the constitutional structure, which was included in the General Framework Agreement in 1995. The idea of international actors to re-create the state of Bosnia, and ensure full refugee return, human and minority rights protection, and implement democratic governance through power-sharing was always an illusion. As will be discussed below, main stakeholders had no interest in the existence of Bosnia as a functional state, secessionist tendencies were not dampened down by the federal structure, but instead autonomy enabled certain actors to develop an independent and confrontational political agenda. Until today Bosnia remains a contested country, and neither the "pull of Brussels" in the context of EU integration, nor demands and threats by the international donor community (most notably the IMF), have resulted in fundamental changes. The state remains weak and internally contested, the system has not become self-sufficient and the three main nation- and state-building projects continue to undermine the existence of a Bosnian identity and a functional Bosnian state. While a new emphasis on ethnic and national difference has been institutionalized 
through strict power-sharing and divergence in educational, cultural, linguistic and societal practices, religion remains the main dividing force in Bosnia. The contest over group rights versus human rights and more integration vs. more autonomy continues in the country.

\section{Contemporary Issues and the Relevance of Religion Today}

In recent years one issue more than any other has dominated political debates in Bosnia: the question of constitutional reform. Already in 2005, there was an initiative from the American embassy to agree on a number of reforms of the current system, including the creation of new ministries and the softening of certain power-sharing provisions. However, this initiative failed to gain the required twothird majority in the House of Representatives in April 2006. Since then a number of initiatives have been started, both by local elites and by international actors. All of them have failed to materialize (Perry 2014). In December 2009, the European Court of Human Rights (ECtHR) ruled in its famous decision of Sejdic and Finci versus Bosnia that Bosnia's current constitutional framework discriminates certain groups, as they are not allowed to stand for the office of the Presidency and the House of Peoples. Hence, the Court ruled that Bosnia would have to change its constitution within six months to address this issue and fulfill its international obligations as a member of the Council of Europe. However, until today political elites have failed to reach an agreement on any form of changes to implement the judgment, demonstrating the lack of political will and the general problems of stagnation in a power-sharing system, in which nobody really wants to "share", i.e compromise and find consensus (Keil 2013b). The judgment of the ECtHR has resulted in a new discussion about the future of the Bosnian state. As described above, the war between 1992 and 1995 was about the relationship of three national groups to the state Bosnia as well as to each other. This complex issue has not been resolved even today and in recent years there have been new calls for changes by the main political actors.

Bosnian Serbs support the Dayton Agreement and the vast autonomy of the RS in the current system. They have also begun to undermine reforms that have been agreed in the post-war years to devolve decision-making powers back to the entity level. This is most visible in the area of media rights, but also includes areas such as legal reform, highway construction, the fight against corruption and organized crime and agriculture and industry. In the light of the independence of Kosovo in 2008 and heightened tensions in Bosnia, there has also been a more open challenge to the territorial integrity of the state by putting a referendum on the independence of the RS back on the agenda. This demonstrates that Serbs see Bosnia as an artificial construct, a union of three constituent peoples, which-have agreed on the state and formed the state and consequently they can voluntarily leave the state at any time. However, international actors, as well as Bosniaks and Croats have disagreed with this view and have openly warned of further conflict in the country and even a return to violence. ${ }^{15}$

Croats, too, have started to openly challenge the current institutional make-up of the country:Aarguing that the FBiH discriminates against Croats in Bosnia, because it is dominated by Bosniaks. 
They feel that the current institutional make-up renders Croats from the smallest group into the position of a minority both within the FBiH and at a central level. Their main claim is that they also need their own entity and that Bosnia should be split up into multiple regions, of which at least one has a Croat majority (Keil and Woelk 2014). In contrast to the demands by Serbs, which have openly suggested a referendum on the independence of the RS, Croats do not as such questiondo not question the territorial integrity of Bosnia as such. This has to do with a lack of support for such an action from Croatia, where politicians from all political backgrounds have supported Bosnia's territorial integrity since the end of the Tudjman regime in 1999/2000. Yet, Croats feel marginalized within the current structures and openly question the current system.

Finally, Bosniaks are also unhappy with the current political framework. Most Bosniak parties argue that Dayton created an unmanageable state, and that centralization and further changes are required. While they differ in the specifics of their demands, most Bosniak parties argue for a stronger central state and the abolition of the entities, which they perceive as a result of the war (and encompassing ethnic cleansing). They also promote the idea of a liberal democracy in which oneperson/one-vote and human rights would be the main guiding principles. This would of course favor Bosniaks as the largest group in Bosnia, and it has been strongly opposed by Serbs and Croats alike. For a long time Bosniaks supported the efforts for further centralization by international actors, however, they have been less supportive when their own political advantages were at stake. They, too, have not supported effective anti-corruption agencies to develop, and their insistence on the abolition of the RS police has prevented agreement on a police reform in 2006 and 2007.

This implies that Bosnia remains a contested country. Federalism, the tool used to manage the conflict between the three constituent peoples, remains a disputed concept in the country. The very principle of “constituent peoples” has become contested ever since the ECtHR judgment in 2009. There is no agreement on the basic nature of the Bosnian state as a state of three constituent peoples, despite the references in the constitution. Bosnia remains an artificial monster in the eyes of some Bosnian Serb politicians. For Bosniaks, the current framework has allowed the results of ethnic cleansing to become successfully institutionalized in the current structures by legitimizing the homogenous territories through the current federal framework. Many Croats feel that they are permanently discriminated against as the smallest of the constituent peoples. Identity conflict and nation-building projects continue to dominate daily Bosnian politics. In this context religion remains of key importance. Darko Sejdic, a Roma rights activist and Jakob Finci, the leader of Bosnia's Jewish community, who initiated the ECtHR judgement, are members of marginalized ethnic and religious groups in Bosnia. They demonstrate that the strong connection between ethnic/national identity and religion has meant that other religious groups have been discriminated in the current institutional framework, and remain marginalized in Bosnian society. Furthermore, representatives of the Catholic Church in Bosnia as well as from Croatia have played a vital role in strengthening Croat identity in Bosnia. During the 
recent census in the country (October 2013), he askedleading Bishops in Bosnia and Croatia asked all Catholics in Bosnia to identify as "Croat", thereby strengthening the link between national and religious identity (Malagic 2013). The Islamic Community in Bosnia has also commented on the census by complaining that it divides the Bosniak nation between those that declare themselves as "Bosniak" and those that state they are "Bosnian" (Jukic 2013a) thereby openly promoting the association of the Islamic Community with the identity of "Bosniak." Interestingly, the selfidentification of Bosnian Muslims as "Bosnians" instead of "Bosniaks" is a clear choice of identifying with the state/territory they live in instead of any form of identification that has religious contours. -In a similar vein, the Serbian Orthodox Church has also contributed to nation-building and the connection of Serb identity and Orthodox faith, for example through the building of new Orthodox Churches in areas that before the war had a Bosniak majority (Jukic 2013b). The religious communities continue to play a key role in supporting the nation-building projects in Bosnia. The institutionalized privileges of the three constituent peoples have however meant that alternative voices, be they religious or political, remain marginalized and ignored.

\section{Conclusion}

Religion remains of key importance in contemporary Bosnia. It is the most important national marker and the religious communities support different nation-building (and state-building) projects in the country. The three constituent peoples dominate the majority of the institutions at central and regional level in Bosnia. These groups are strongly associated with specific religious communities and these communities have strongly identified with these constituent peoples.

The current political system in the country attempts to balance the different demands of three groups by providing them with far-reaching autonomy on the one side through a highly complex federal system, and power-sharing provisions on the other side. However, the system so far has failed to address the on-going struggle of what kind of state Bosnia is and how it addresses the opposing demands of Bosniaks, Serbs and Croats. While international actors have played an important role in ending the conflict and building a more effective state, they too have been unable to solve the underlying issue of what kind of state Bosnia is, and what the relationship of the three constituent peoples to the state is. As long as there is no general consensus on the nature of the state, and as long as there is no agreement on Bosnia as a multinational and multi-religious federal state, it is unlikely that the country will implement important reforms and move closer towards membership in the EU. More than a decade after the Dayton Agreement it remains to be seen if Bosnia will be an example of a successful multinational federal democracy.

\section{References}

Babuna, A. (1999) Nationalism and the Bosnian Muslims. East European Quarterly, 23/2, 195-216. 
Bassuener, K. (forthcoming 2014) 'Virtual Deterrence: BiH's Institutionalized Insecurity and the International Flight from Responsibility' in: S. Keil and V. Perry (eds) State-Building and Democratization in Bosnia and Herzegovina (Farnham and Burlington, Ashgate).

Belloni, R. (2007) State Building and International Intervention in Bosnia (Basingstoke and New York, Routledge).

Bieber, F. (2006) Post- War Bosnia (Ethnicity, Inequality and Public Sector Governance) (Basingstoke, Palgrave McMillian).

Bieber, F. and Keil. S. (2009) Power-Sharing Revisited: Lessons learnt in the Balkans? Review of Central and Eastern European Law, 34/4, 337-360.

Bildt, C. (1998) Peace Journey: The Struggle for Peace in Bosnia (London, Weidenfeld and Nicolson).

Burg, S. and Shoup, P. (1999) The War in Bosnia-Herzegovina (Ethnic Conflict and International Intervention) (Armonk and London, M.E.Sharpe).

Burgess, M. (2012) In Search of the Federal Spirit (Oxford and New York, Oxford University Press).

Chandler, D. (ed) Peace Without Politics? Ten Years of International State-Building in Bosnia (London and New York, Routledge).

Chandler, D. (2000) Bosnia (Faking Democracy After Dayton), (2nd edition London and Sterling, Pluto Press).

Chesterman, S. (2005) You, The People, The United Nations, Transnational Administration, and StateBuilding (Oxford and New York, Oxford University Press).

Daalder, I. (2000) Getting to Dayton: The Making of America's Bosnia Policy (Washington D.C. Brookings Institution Press).

Hoare, M.A. (2007) The History of Bosnia: From the Middle Ages to the Present Day (London, Saqi Books). 
Hoare, M.A. (2004) How Bosnia Armed (London, Saqi Books).

Huntington, S. (1993) The Clash of Civilizations. Foreign Affairs, 72/3, 18-38.

Jukic, E. (2013a) Bosnian Census Accused of Dividing Bosniaks in: Balkan Insight, 29 April, see: http://www.balkaninsight.com/en/article/bosnia-muslims-complain-over-landmark-census (accessed 10 December 2013).

Jukic, E. (2013b) Church Accused of 'Senseless Provocation' in Srebrenica in: Balkan Insight, 18 April, see: http://www.balkaninsight.com/en/article/orthodox-church-urged-to-end-construction-insrebrenica (accessed 10 December 2013).

Keil, S. and Woelk, J. (forthcoming 2014) 'The Territorial Dimension of the Croat Question in Bosnia and Herzegovina' in: Konrad Adenauer Stiftung in Bosnia and Herzegovina (ed.) Constitutional Reform and the Croat Question in Bosnia and Herzegovina (Sarajevo, Konrad Adenauer Stiftung).

Keil, S. and Perry, V. (eds) (forthcoming 2014) State-Building and Democratization in Bosnia and Herzegovina (Farnham and Burlington, Ashgate).

Keil, S. (2013a) Multinational Federalism in Bosnia and Herzegovina (Farnham and Burlington, Ashgate).

Keil, S. (2013b) Legal Misunderstandings, False Normative Hopes and the Ignorance of Political Reality (A Commentary on the Recent ESI Report “Lost in the Bosnian Labyrinth”) DPC Policy Note New Series \#4, (Canterbury, November).

Keil, S. (2012) Federalism as a Tool of Conflict Resolution-The Case of Bosnia and Herzegovina. L_e Europe en Formation, 54, 205-218.

Knaus, G. and Martin, F. (2003) Lessons from Bosnia and Herzegovina: Travails of the European Raj. Journal of Democracy, 14/3, 60-74.

Malagic, M. (2013) Bishops Call on Religious Followers to Participate in the Upcoming BiH Census in: Independent Balkan News Agency, see: ttp://www.balkaneu.com/bishops-call-religious-followersparticipate-upcoming-bih-census/\#sthash.6VBcZH7a.dpuf (accessed 10 December 2013).

Malcolm, N. (2002) Bosnia. A Short History (Basingstoke, Pan Books). 
McMahon, P. and Western, J. (2009) The Death of Dayton (How to Stop Bosnia from Falling Apart). Foreign Affairs, 88/5, 69-83.

Perry, V. (forthcoming 2014) 'Constitutional Reform Processes in Bosnia and Herzegovina: TopDown Failure, Bottom-up Potential, Continued Stalemate’ in: S. Keil and V. Perry (eds) StateBuilding and Democratization in Bosnia and Herzegovina (Farnham and Burlington, Ashgate).

Spiric, N. (2007) in: Bosnian Prime Minister Resigns amid Tensions in: Financial Times, $2^{\text {nd }}$ November 2007.

Toal, G. and Dahlman, C. (2011) Bosnia Remade: Ethnic Cleansing and Its Reversal (Oxford and New York, Oxford University Press).

\section{Endnotes}

\footnotetext{
${ }^{1}$ On the issue of new federal models and the revival of the federal idea, see Burgess 2012.

${ }^{2}$ Following the general use of term, the short form Bosnia will be used. If not otherwise stated, this always refers to the whole country.

${ }^{3}$ This data and all following relate to the census in 1991. There has been a census in October 2013, however the data was not yet available when this paper was written (November 2013).

The data of the 1991 census reveals that $43.4 \%$ of the population declared themselves as Bosniak, $31.2 \%$ as Serbs and $17.4 \%$ as Croat. The rest is made up of minorities (Roma, Jews, Albanians etc.); more than $5 \%$ also declared themselves as "Yugoslavs."

${ }^{4}$ Case of Sejdic and Finci vs. Bosnia and Herzegovina, applications 27996/06 and 34836/06.

${ }^{5}$ They were recognised under the name "Bosnian Muslims." An assembly of leading Muslim intellectuals and politicians adopted the name "Bosniaks" in 1993. This was seen as a way to get rid of the label "Muslim” in the midst of the Bosnian war, and they hoped that this would make it easier for Western powers to intervene and support them in the conflict.

${ }^{6}$ The leader of the Bosnian Muslims/Bosniaks in the early 1990s, Alija Izetbegovic, for example, was arrested by the Yugoslav Communists because he published an "Islamic Declaration” in 1970. This publication was later used by Serb and Croat nationalists to underpin their claim that Muslims in Bosnia were trying to establish an Islamic state.

${ }^{7}$ Bosnia's federalism is a result of the Dayton Peace Agreement in 1995. International actors, mainly the USA and the European Union, had a major impact on the Constitution of Bosnia and the political development in postwar Bosnia.

${ }^{8}$ Practically, however, this has very little relevance in Bosnia, as the vast majority of Serbs are Orthodox, literally all Croats are Catholic and the majority of Bosniaks are Muslims. However, this differentiation between ethnic/national identity and religious identity matters, when it comes to including those that actually practice the religion. Bosnia has been known for a long time for its liberal, open and Western version of Islam, most
} 
Bosniaks do not pray five times a day and do not fast. While Croats remain active in practising religion in Bosnia, there has been a rise of Orthodox Church goers since the war.

${ }^{9}$ There have been numerous attempts to translate the Constitution into local languages (Bosnian, Serbian and Croatian), but the major parties have been unable to agree on a translation.

${ }^{10}$ A great summary of the situation in Bosnia shortly after the war can be found in the autobiography of the first High Representative of the International Community, Carl Bildt. See Bildt 1998.

${ }^{11}$ The details of the decision can be found in the minutes of the Bonn summit of the Peace Implementation Council, which oversees the implementation of the General Framework Agreement for Peace in Bosnia and Herzegovina. See: http://www.ohr.int/pic/default.asp?content id=5182 Point XI.2.

${ }^{12}$ The High Representative was not the only international actor that had substantial intervention rights in Bosnia. The Organization for Security and Cooperation in Europe (OSCE) organized all elections in the country until 2002, including deciding on the electoral laws and which parties were allowed to stand. Furthermore, NATO and the International Police Task Force in the country were allowed to vet, dismiss and arrest military and police officials and those indicted for war crimes. Today, many of these tasks are performed by the EU, which took over the military and police missions in Bosnia, and is now the most important international actor. Since 2006, no High Representative has taken a less interventionist position, most recently abstaining from any intervention. ${ }^{13}$ While Bosnia has established some multi-national military units, these remain relatively homogenous, and as Bassuener argues, could be untangled in case of conflict relatively easily. See Bassuener 2014.

${ }^{14}$ On this debate see for example Chesterman 2005, the contributions in Chandler 2008 and the different contributions in Keil and Perry 2014, which assess the successes and failures of state-building and democratization in Bosnia.

${ }^{15}$ Although a return to open violence and war seems unlikely today the peace remains fragile and open challenges to the current constitutional order remain a key element of the political discourse. See for example: McMahon and Western 2009. 